Journal of Advanced College of Engineering and Management, Vol 6, 2021

\title{
Land Use Land Cover (LULC) Change Projection in Kathmandu Valley using the CLUE-S Model
}

\author{
Suraj Lamichhane ${ }^{1,2}$, Narendra Man Shakya ${ }^{1}$ \\ ${ }^{1}$ Institute of Engineering, Pulchowk Campus, Lalitpur \\ ${ }^{2}$ Interdisciplinary Research Institute for Sustainability, IRIS, Kathmandu, Nepal \\ Email Address: surajlamichhane@ioe.edu.np
}

\begin{abstract}
In the past few decades the urbanization pattern of the Kathmandu valley has rapidly increased and the process was sensed through the increase in the urban facilities, population growth, and changed LULC pattern. The historical LULC change was analyzed using the generated map and the future scenario was found through the CLUE-S LULC change model and processed in GIS environment. Five scenarios and nine driving forces were considered for the sensitivity and future analysis of the model. Based on the evaluation of the historical maps and the conservation matrix, the built-up area is found to be increased nearby by $5 \%$ and the agricultural area decreased by $6.5 \%$ during 2010 to 2018 . It is concluded that the normal LULC conservation scenario provides more reliable information for the future projection. The simulation result highlights that nearly $4 \mathrm{~km}^{2}$ of fertile and open area will be converted to built-up areas due to the rapid urbanization per decade. This increase in urbanization process leads to more challenges in urban environment management in future.
\end{abstract}

Keywords: CLUE-S model, Kathmandu Valley, LULC change.

\section{Introduction}

Nepal lies in the least ten urbanized countries in the world and also, it is the top ten fastest urbanization rate countries having 3\% urban growth rate (UN DESA, 2018). Kathmandu Valley, Pokhara Valley, inner Tarai valley, and border towns near the East-West Highway are the major urban centers in Nepal. Among them, Kathmandu Valley (KV) is the most populated and rapidly growing urban area and nearby $29 \%$ of national urban population resides in this valley (MoUD, 2017). The urban density of the Kathmandu Valley is above 10000/sq.km; whereas, core city area have more than average, e.g. Kathmandu (19726/sq.km), Lalitpur (14574/sq.km), and Bhaktapur (12662/sq.km) and similarly periurban area has less than average 4445/sq. km (CBoS, 2011). In future, the tendency will be more in the peri-urban area of the valley due to excess of open areas and nominal cost of land compared to the core urban area. The urbanization pattern of the city is observed in terms of increase in population density, LULC change, and the change in urban facilities and environment (Lamichhane and Shakya, 2019a).

Thapa and Murayama (2011) analyzed the past complex urban growth pattern of the Kathmandu Valley $(685 \mathrm{~km} 2)$ and devised some suggestions for reducing the impact on the urban environment. The past base maps $(1978,1991$, and 2000) were produced using remote sensing satellite data and processing in GIS tools. They concluded transformation of built-up area is by $8.17 \%(32 \mathrm{~km} 2)$ due to reduction in the agriculture and forest area. The expansion of the built-up area has been observed around the ring-road and radial feeder roads from the ring-road. The land changing process has escalated since the 1980s. Spatial diffusion of urban/built-up areas has spread outward from the city core and along the major roadways. Expansion of the road network and easy accessibility of the nearest market, and farmers have been motivated for an agricultural activity that reduced the shrubs and forest land. Such economic activity, business opportunity, modern facility, and the better lifestyle, pull the people towards the urban area(Van Hear et al., 2018). The high rate of population migration with multi-culture, socioeconomic change, and haphazard urbanization creates an imbalance in the urban environmental health, use of natural resources, and change in land-use practices of the Kathmandu Valley(Rimal et al., 2017).The population growth and its implication in land-use change scenario from 1976 to 2015 was jacem, Vol 6, 2021 
analyzed through the conversion matrix, the urban built-up area was increased by $+12.8 \%$ and reduce the other open land. The past urban development trend of the KV indicates that the future open area (such as agriculture, open, bush area) will be converted into concrete jungle around the road corridor. Similar type of historical development and expansion of the valley has been detected through the LULC change pattern from the various studies (Ishtiaque et al., 2017; Paudel et al., 2016; Rimal et al., 2017).

Urbanization and the rate of LULC change are both global and local problems in land and resources management. To prepare the future plan, projected LULC map is required for different development scenarios. Population growth rate in urban areasis duly related to physical facilities that are driving forces for the future LULC change. Many researchers developed various models for the projection of future LULC change based on driving forces like Markov Chain and genetic algorithm (Tang et al., 2007), cellular automata coupling with fuzzy logic (Liu et al., 2011), statistical model (Tran et al., 2017), weight of evidence (Thapa and Murayama, 2011), and artificial neural network (Almeida et al., 2008; Li and Yeh, 2002), CLUE-S (Verburg et al., 2002), Dinamica EGO (Soares-Filho et al., 2009), GEOMOD(Praskievicz and Chang, 2011), Land use Sim(Pratomoatmojo, 2018) and Land Change Modeler (LCM) (Kim, 2010) etc. All of these models have used the input information of socioeconomic and biophysical land use change as driving forces (topography, slope aspect, population, settlements, river networks, road networks, etc.) that play the spatio-temporal change effects in area. Various studies have been conducted in the Kathmandu Valley based on the driving forces and various empirical LULC change model (Dahal et al., 2019; Rimal et al., 2018; Thapa and Murayama, 2012). The future expansion of the built-up area, encroachment of fertile land, land fragmentation, increase in the flood frequency and magnitude(Lamichhane and Shakya, 2019b; Thapa et al., 2020), and reduction the recharge tendency (Lamichhane and Shakya, 2020) due to anthropogenic activities have been dismantling the urban environmental equilibrium in the valley.

All the above studies used models for regional scale studies and it is better to simulate the regional level but for the small areas the Conversion of Land Use and its Effects at Small regional extent (CLUE-S) model gave the better performance as per the previous study (Jiang et al., 2015; Verburg, 2010; Verburg et al., 2002; Zhou et al., 2013). The CLUE-S is an empirical model to simulate the land use change based on local characteristics change with the dynamic temporal and spatial distribution of land requirement. In this model, the study area is divided into small grids and land use characteristics are defined. The driving forces are identified and the input data of each driving forces (geology, slope, aspect, population density, settlement, river network, road network, etc.) are prepared by using GIS tools. In this context, the total study area of the Kathmandu valley is small and the model performs better than the others. The availability of data sources and the requirement of the model are more compatible, so this model is used in the context of KV and similar area. The evaluation of future LULC change and the decadal analysis are the main objectives of the study.

\section{Materials and methods}

\subsection{Study area}

The Kathmandu Valley (27032'13" and 27049'10"N latitude and 85011'31" and 85031'38"E longitude) is the capital city of the Nepal, which is located in central Nepal has forest covered mountain in surrounding. Fewer slopes or the plain area is used for agriculture and settlement purposes. Five types of land category (forest, water body, built-up area, agriculture land, and restricted area) were created for analysis. The study area is as per Fig. 1 represents all the urban areas and possible urbanization locations of three districts (Kathmandu, Lalitpur, and Bhaktapur). 

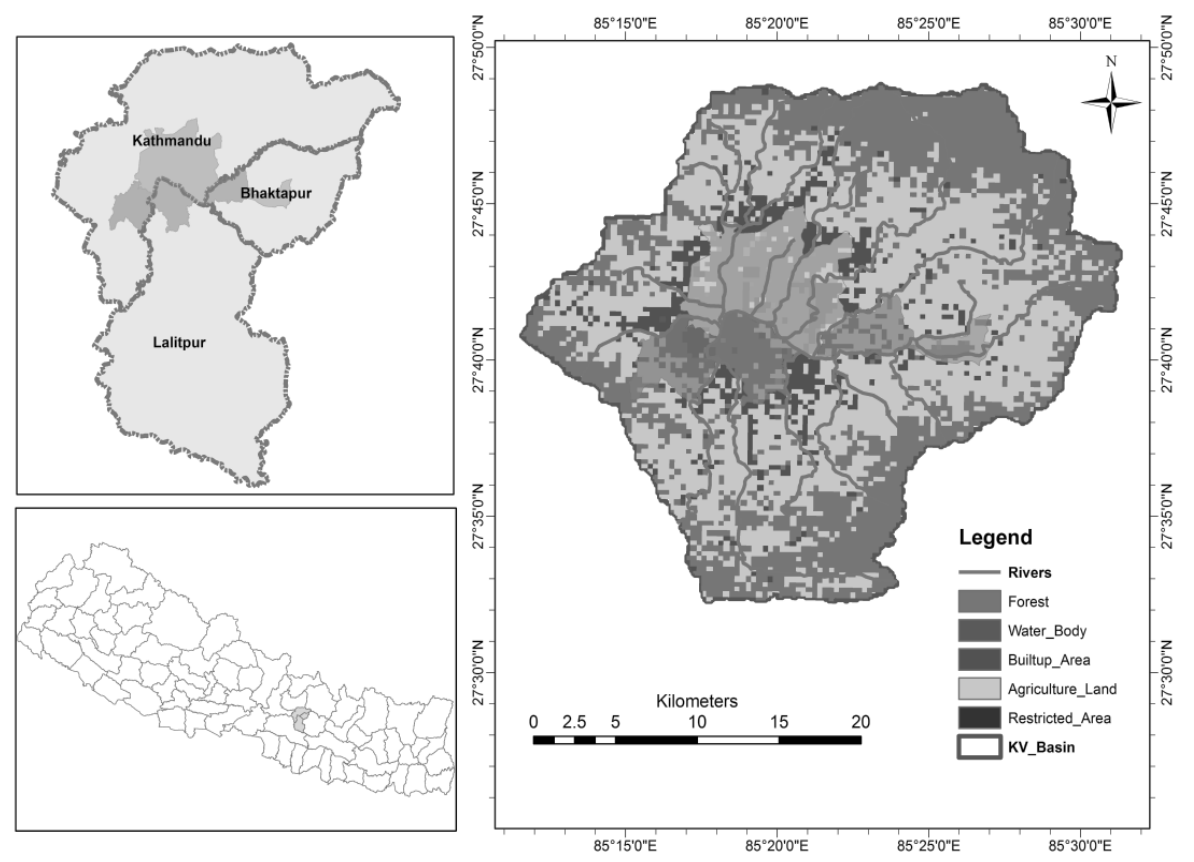

Fig 1: location map of the Kathmandu Valley

Bagmati River is the only one drainage network with several tributaries such as Bishnumati River, NakhuKhola, BalkhuKhola, Manohara, DohobiKhola, etc. Mostly the climate is semi-tropical in the study area and precipitation mostly occurs during monsoon season. The monthly average maximum and minimum temperatures vary from $29.80 \mathrm{C}$ to $3.40 \mathrm{C}$ and the average humidity of the basin is $75 \%$ (DHM, 2015). The favorable climate and the urban facility pull the people to migrate in the valley. Kathmandu, Lalitpur, Bhaktapur, Kritipur, Thimi are the major settlement in the valley. As per the earlier administrative structure (CBS, 2012), the valley demography, population and household are presented in Table-1. The historical population and household statistics highlight the urban growth pattern in the valley.

Table 1: Population and associated details of the Municipality in the KV

\begin{tabular}{|c|c|c|c|c|c|c|}
\hline $\begin{array}{c}\text { S. } \\
\text { N }\end{array}$ & Municipality & $\begin{array}{c}\text { Area } \\
\left(\mathrm{km}^{2}\right)\end{array}$ & $\begin{array}{c}\text { HH (\# } \\
\text { household }) \\
2001\end{array}$ & HH 2011 & $\begin{array}{c}\text { Population } \\
2001\end{array}$ & $\begin{array}{c}\text { Population } \\
2011\end{array}$ \\
\hline 1 & $\begin{array}{c}\text { Kathmandu } \\
\text { Metropolitan City }\end{array}$ & 49.49 & 152155 & 254292 & 671846 & 975453 \\
\hline 2 & $\begin{array}{c}\text { Lalitpur Sub- } \\
\text { Metropolitan City }\end{array}$ & 15.15 & 34996 & 54581 & 162991 & 220802 \\
\hline 3 & $\begin{array}{c}\text { Bhaktapur } \\
\text { Municipality }\end{array}$ & 6.56 & 12133 & 17639 & 72542 & 81748 \\
\hline 4 & Kritipur Municipality & 14.76 & 9487 & 19441 & 40835 & 65602 \\
\hline 5 & $\begin{array}{c}\text { Madhayapur } \\
\text { Municipality }\end{array}$ & 11.11 & 9551 & 20302 & 47751 & 83036 \\
\hline
\end{tabular}

\subsection{Data}

For the analysis of the historical and the projected LULC change using the CLUE-S model, topographical and socioeconomic layers of the study area wereanalyzed and processed in the GIS environment. The list of the information and data sources are listed in Table 2. 
Table 2: List of the used data and sources

\begin{tabular}{|l|l|l|l|l|}
\hline Type of Data & Sources & Resolution & $\begin{array}{l}\text { Year/ } \\
\text { Length }\end{array}$ & Processing tools \\
\hline DEM & ASTER GDEM version 2 & $30 \mathrm{~m}$ & & ArcGIS - 10.2 \\
\hline Geology & $\begin{array}{l}\text { Department of Mines and } \\
\text { Geology }\end{array}$ & $1: 50000$ & 1998 & ArcGIS - 10.2 \\
\hline $\begin{array}{l}\text { Land use/ cover } \\
\text { (LULC) }\end{array}$ & $\begin{array}{l}\text { USGS (Land sat 5 to } 8 \\
\text { image) and ICIMOD }\end{array}$ & 30 & $\begin{array}{l}2010 \\
2018\end{array}$ to & ArcGIS - 10.2 \\
\hline Population & CBoS, Nepal & $1991-2011$ & $\begin{array}{l}1991,2001, \\
2011\end{array}$ & \\
\hline Settlements & Department of Survey & $1: 25000$ & 2010 & ArcGIS - 10.2 \\
\hline Market & Department of Survey & $1: 25000$ & 2010 & ArcGIS - 10.2 \\
\hline Road Network & Survey Department & $1: 25000$ & 2010 & ArcGIS - 10.2 \\
\hline
\end{tabular}

\subsection{Methodological framework}

Nine geo-physical driving forces layer were considered for the analysis, five future projection scenarios were generated from the historical LULC data and those scenarios were used for the decadal LULC change analysis of the study area as per Fig. 2. For the projection of LULC map, CLUE-S model was used as shown in Fig. 2.

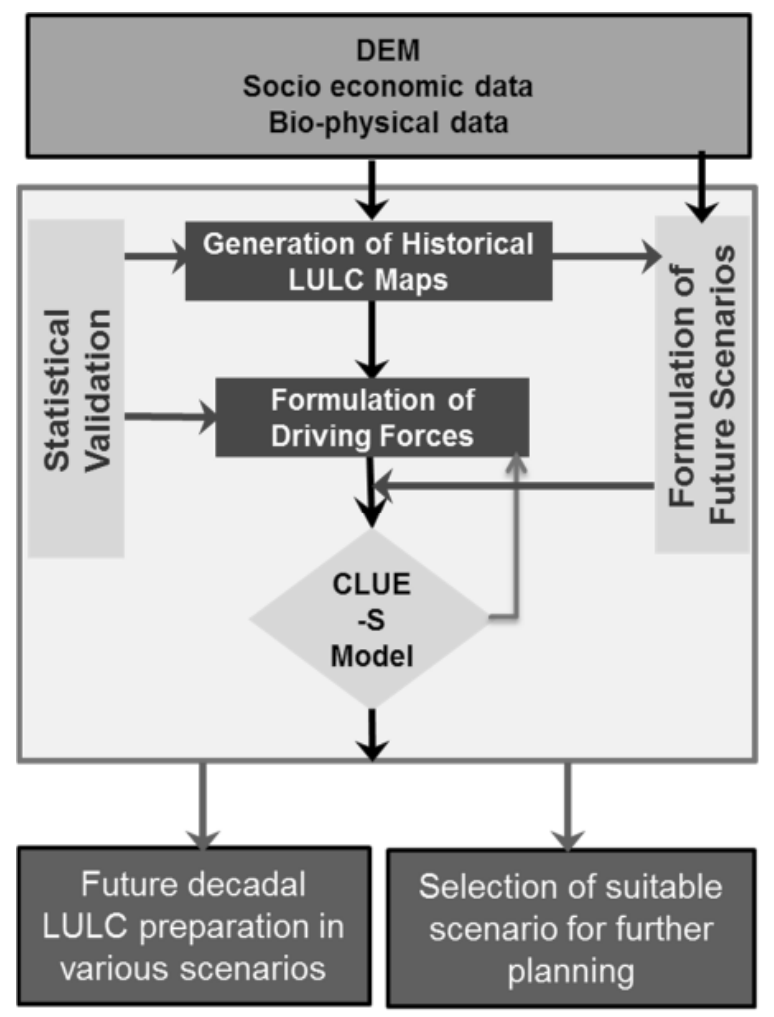

Fig 2: Methodological framework of the study

\subsection{Generation and evaluation of historical LULC map}

Land use/cover (LULC) maps of the study area for the period of 2010 to 2018 were prepared by processing of the Landsat image obtained from United States Geological Survey (USGS) web portal. Clear and less cloud effect image was used for the processing. The images were processed and analyzed using Geographic Information System (GIS) tools. A supervised classification technique was used for the generation of LULC map. Only five types of LULC category (agriculture, built up, forest, water 
body, and restricted area (like airport, park, administrative office area, cultural area, etc.) were used in the LULC map in this study. The generated map was compared with the ICIMODLULC data after categorizing the same LULC type. The Kappa statistics (K) was used as a measure of agreement (or evaluation) between the two maps. The Kappa values vary from zero to one. The maximum value (means one) represents the most perfect agreement between two maps and zero means no level of agreement (Cohen, 1960). The K value can be represented by Eq.-1 as follows:

$K=\left[\frac{\operatorname{Pr}(a)-\operatorname{Pr}(e)}{(1-\operatorname{Pr}(e))}\right]$

Where, $\operatorname{Pr}(\mathrm{a})$ is the observed relative agreement among all rasters and $\operatorname{Pr}(\mathrm{e})$ is the hypothetical probability of a chance of an agreement.After finding the good agreement between the two maps of 2010, similar process and the signature file was used for the generation of the others year (2012 to 2018) map in GIS environment.

\subsection{Projection scenario analysis}

Future projection of the LULC demand was basically categorized into economic and conservation scenarios. In economic scenario, the future LULC demand was forecasted based on the different economic indicators and developed the empirical relation between the indicator and LULC demand. The conversion scenario basically deals with the future government planning considering certain restrictions in the LULC type. It is also called the restricted scenario(Shrestha et al., 2018). For the future analysis, the economic scenario was adopted. The projection of the LULC demand was done based on the LULC change and population growth rate in the Kathmandu Valley as follows.

a) Normal LULC change scenario: - This analysis was based on the actual historical LULC change rate. The actual LULC change data was found from the generated historical LULC map or dataset. In this scenario, normal LULC change pattern of the study area was adopted and it is assumed that the all LULC change factors will have same trend in the future.

b) Double of normal LULC change scenario: - In this scenario, the urban population and urbanization pattern of the study area will go up rapidly compared to the historical pattern. So, it was assumed that the LULC change trend is double than the historical.

c) Half of normal LULC change scenario: - It is the restricted scenario, in which, the trend of the LULC change is already controlled and future projection rate will be half of normal LULC change trend.

d) Population growth rate scenario: - The population growth rate of the urban area is much higher than the historical built-up area change rate. In this scenario, the rate of increase in population is correlated with the household number. Then rate of change of the LULC pattern is determined based on the increase in the household number.

e) Half of population growth rate scenario: - It is also restricted scenario, in which the population and household growth rate are considered as half of the historical trend. It is also assumed that the other relative factors influencing population growth are controlled.

\subsection{Formulation of CLUE-S model}

LULC change in the developing area has an empirical, positive, and exponential relation with urbanization and it was easily observed through historical urbanized area and its corresponding LULC change. All land use change model is conceptualized through this principle. The urbanization pattern and LULC change are the complex relationship with economic development and these complex phenomena is discretized into the small driving forces for solving. Bio-physical and socio-economic factors are considered as the driving forces (Yin et al., 2011)(geology, slope, aspect, population density, jacem, Vol 6, 2021

Land Use Land Cover(LULC) Change Projection in Kathmandu Valley using the CLUE-S Model 
settlement, river network, road network, etc.)for the LULC change and the analysis is done as the probabilistic approach with respect to the weightage of each driving forces in each LULC type, as per EQ.21 and Fig-3(Verburg et al., 2002).

$R_{k i}=a_{k} X_{1, i}+b_{k} X_{2, i}$

Where $\mathrm{R}$ is the preference to devote location $\mathrm{i}$ to land use type $\mathrm{k}$,

$\boldsymbol{X}_{\mathbf{1}, \boldsymbol{i}}$, are biophysical or socio-economical characteristics (driving forces) of location i and

$\boldsymbol{a}_{\boldsymbol{k}}$ and $\boldsymbol{b}_{\boldsymbol{k}}$ are the relative impact of these characteristics on the preference for land use type k.

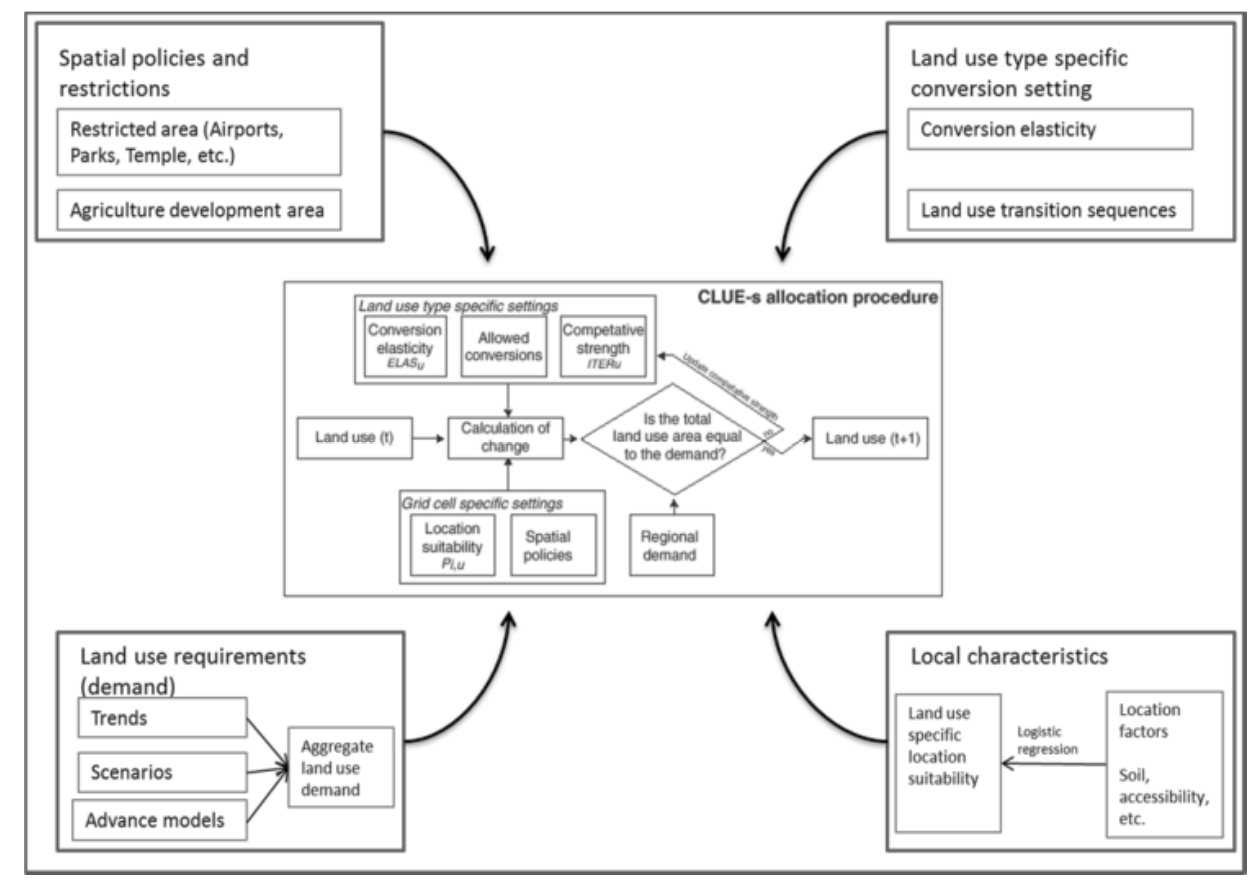

Fig 3: Working principle of CLUE-S Model

Initially, the study area was divided into the reliable grid size $(300 \mathrm{~m} \times 300 \mathrm{~m})$ as per limitation of the model and the response variable (spatial distribution of land use type) was in a binary number (1 indicated the transition occur and 0 indicated that this grid did not exist and explained)(Verburg et al., 2002). The ordinary logistic regression model was expressed in Eq. 3

$\log \left(\frac{P_{i}}{1-P_{i}}\right)=\beta_{0}+\beta_{1} x_{1, i}------+\beta_{n} x_{n, i}$

Where $P_{i}$ is the probability of specified land use type $\mathrm{i}$ transition in the grid, and, $\beta_{i}$ is a coefficient to be estimated for each explanatory variable $x_{n, i}$.

The logistic regression analysis of the probability for suitability of the land use was analyzed based on the coefficients of the each driving forces in the each land use type by using the Statistical Package for the Social Sciences (SPSS) (Rosner, 2010) tools and goodness of fit of the analysis is checked by the Receiver Operation Characteristics (ROC) value (Pointius and Schneider, 2001). It is generally believed when the ROC value varies between 0.5 and 0.7 , the accuracy of the model is low; when the ROC value varies between 0.7 and 0.9 , the accuracy is credible; and when the ROC value is larger than 0.9 , the model has a high precision (Stephanie et al., 2001). The probability of each grid was calculated based on driving forces and generate the suitability map of different land use and based on actual land use condition define a set of rules to control the difficulties of transitions between land use. The initial land 
use map, suitability map, and land use transition rules was combined for finding the probability of each LULC type. Total probability of each grid for each land use was calculated by the Eq. 4.

$T P R O P_{i, u}=P_{i, u}+E L A S_{u}+I T E R_{u}$

Where, $T P R O P_{i, u}$ is the total probability of cell $\mathrm{i}$ is suitable for land use u. $P_{i, u}$ is the spatial distribution probability obtained by logistic regression; $E L A S_{u}$ is the transition elasticity of land use $u$ and it varies from 0 (lesser stability of the corresponding land use) to 1 (higher stability of the corresponding land use), and $I T E R_{u}$ is the iteration variable of land use u. CLUE-S model was generates the probability of each land use type and corresponding land use map. The result from the CLUE-S was found in the ASCII file and easily analyzed through GIS environments.

\subsection{LULC change analysis}

From the outputs of CLUE-S model, the change in LULC type and its coverage area was found from the map. Initially the historical LULC change during 2010 to 2018 was analyzed through the observation of two maps and formulates the conversion matrix of those LULC change to quantify in percentage and area change. Similarly, all the model simulated data in the various scenarios are also evaluated from the conversion matrix and the appropriate scenario is selected through the statistical indicator (Kappa Value).

\section{Results and Discussions}

Historical LULC change pattern of the valley was established through the generated LULC map. The future LULC map was prepared through the CLUE-S LULC change model based on the past LULC change and the projection scenario. The analysis of the model was done through the empirical equation based on the bio-physical characteristics of each driving forces layer of the basin. The performance of the outputs was evaluated through the Kappa coefficients, ROC value and sensitivity analysis of the various scenario.

\subsection{Generation of Historical data and projection scenario}

The past LULC data of the study area was generated through the USGS web portal Lands at image from 2010 to 2018. The generated 2010 LULC map was evaluated from ICIMOD 2010 LULC map by using the Kappa coefficient $(\mathrm{K})$. The Kappa value 0.68 means the good agreement between the two maps and the process of analysis is in same manner for the others year.

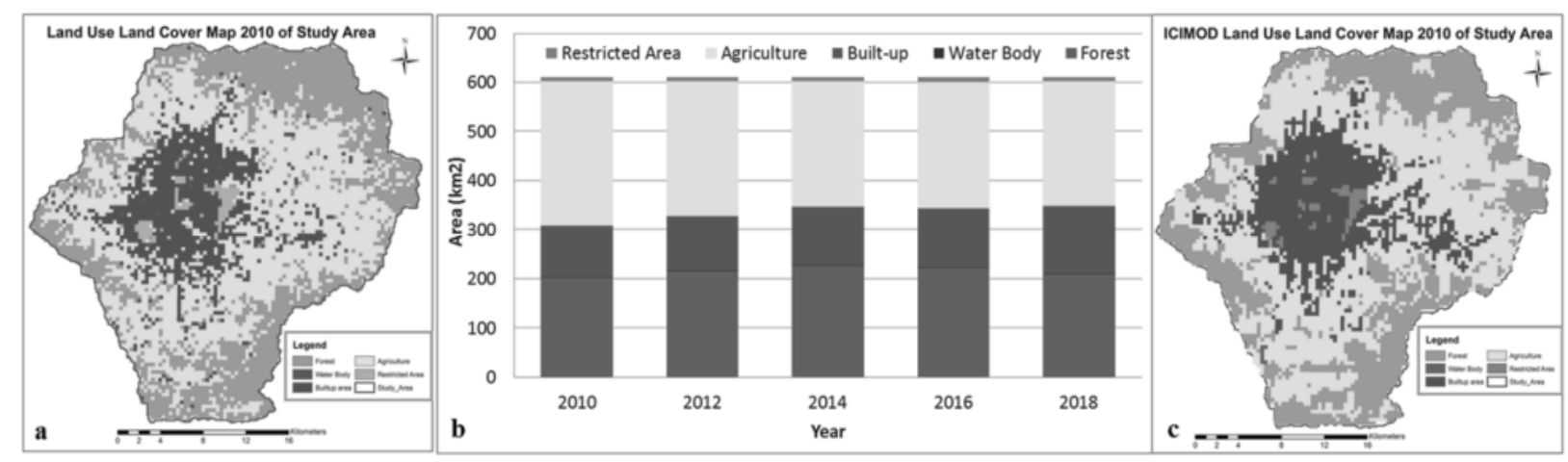

Fig 4: a) Generated LULC map of 2018 b) LULC type with corresponding coverage c) ICIMODLULC map

The output from analysis is shown in Fig-4.The figure highlights that the agriculture area is decreased due to rise in the built-up area between2010and2018 and the conversion matrix is shown in the Table-3. It shown thatthe built-up areas increased by $4.96 \%$ and the agricultural area decreased by $6.51 \%$ during 2010 to 2018 . The built-up area in the valley was accelerating after the earthquake of 2015. The forest 
area has not significantly changed due to the community managed forest. So, for future analysis of the restricted area and water body were considered to be constant.

Table 3: conversion matrix of LULC during 2010 to 2018

\begin{tabular}{|c|c|c|c|c|c|c|c|}
\hline \multirow{2}{*}{\multicolumn{2}{|c|}{ LULC }} & \multicolumn{6}{|c|}{ Land Use/Cover 2018 (\%) } \\
\hline & & \multirow{2}{*}{$\begin{array}{l}\text { Agriculture } \\
\text { Land } \\
32.06\end{array}$} & \multirow{2}{*}{$\begin{array}{l}\text { Built-Up } \\
8.07\end{array}$} & \multirow{2}{*}{$\begin{array}{l}\text { Forest } \\
8.73 \\
\end{array}$} & \multirow{2}{*}{$\begin{array}{l}\text { Restricted } \\
\text { Area } \\
-\end{array}$} & \multirow{2}{*}{$\begin{array}{l}\begin{array}{l}\text { Water- } \\
\text { Body }\end{array} \\
0.04\end{array}$} & \multirow{2}{*}{$\begin{array}{l}\begin{array}{l}\text { Grand } \\
\text { Total }\end{array} \\
48.91\end{array}$} \\
\hline$e^{e}$ & $\begin{array}{l}\text { Agriculture } \\
\text { Land }\end{array}$ & & & & & & \\
\hline 을 & Built-Up & 4.00 & 12.50 & 0.34 & 0.11 & 0.02 & 16.97 \\
\hline$\stackrel{2}{\vdots}$ & Forest & 6.31 & 1.26 & 24.87 & 0.00 & 0.02 & 32.46 \\
\hline$\underbrace{0}$ & Restricted Area & 0.02 & 0.09 & - & 1.31 & - & 1.42 \\
\hline$\underline{n}$ & Water Body & 0.02 & 0.01 & - & - & 0.21 & 0.25 \\
\hline 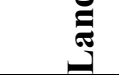 & Grand Total & 42.40 & 21.93 & 33.94 & 1.42 & 0.30 & 100.00 \\
\hline
\end{tabular}

Such increasing pattern of built-up area in the fertile agriculture land will be converted to concrete jungle. The future LULC projection analysis is based on the normal built-up area (as per generated mapsFig-5) and the population growth rate (as per CBoS data base) in the valley and the data shows linear projection.

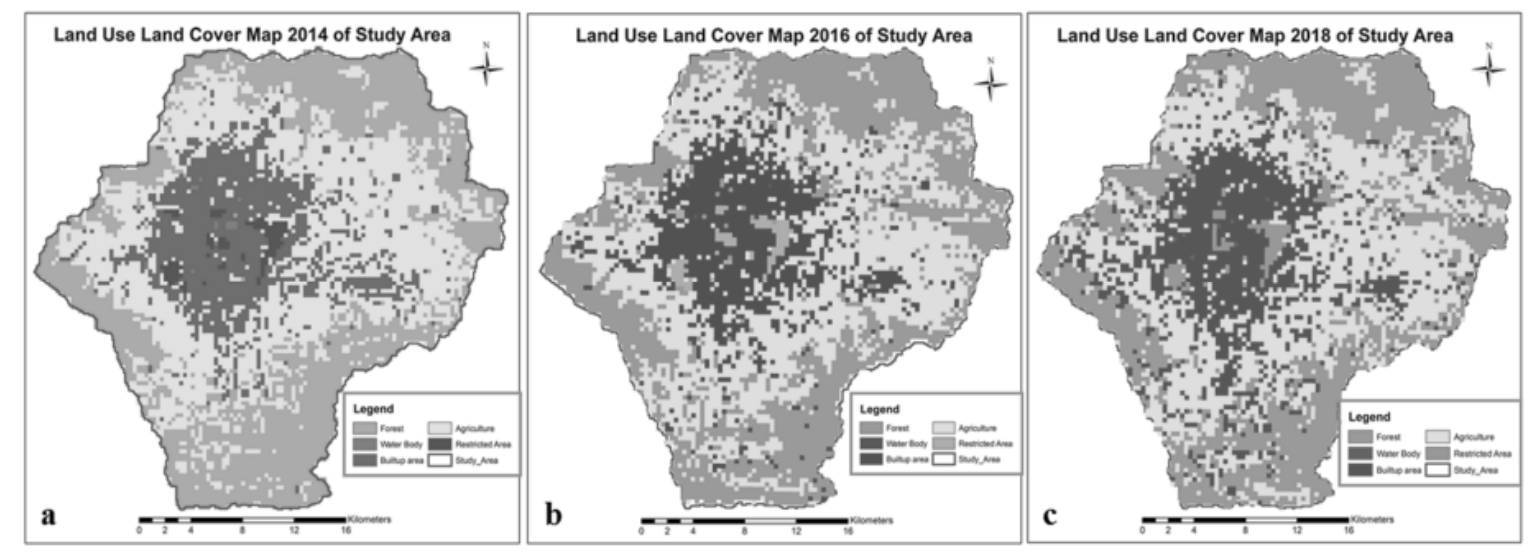

Fig 5: Generated LULC map of a) 2014, b) 2016, c) 2018

\subsection{Driving forces}

In the model, LULC change probability is varied with the neighborhood LULC type and the interrelationship between the driving forces and LULC in each grid cell. The relation was establishedbythe empirical analysis through using logistic regression model. Nine driving forces (geology, slope, soil type, aspect, population density, distance from settlement, distance from river network, distance from road network, etc.) were considered. All these driving forces are correlated with the urbanization process and tendency to shift from the other LULC type. The obtained ROC value $0.92,0.87,0.91,0.83$ and 0.94 of the LULC type forest area, water body, built-up area, agriculture land, and restricted area respectively, represents the strong relation between the driving forces and LULC type. The each grid land use change probability was found by the auto-logistic regression models by using the driving forces as per Eq. 3 . 


\subsection{Future projection through CLUE-S model}

Future projected LULC maps were generated through the CLUE-S environment for the five different projection scenarios as shown Figs. 6 and 7.
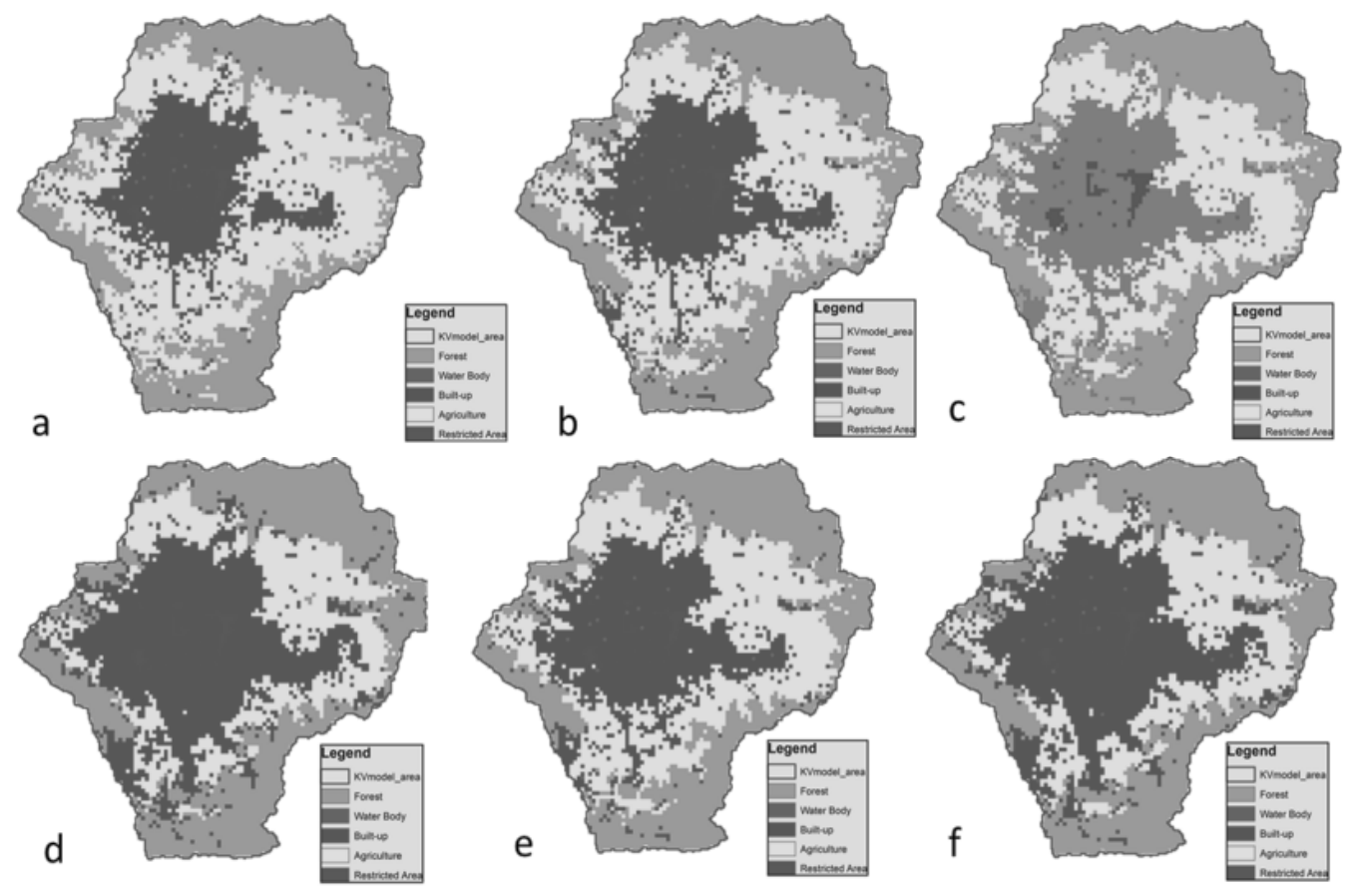

Fig 6: Projected LULC map of a) 2018 base map b) half of normal growth 2030 c) normal Growth $2030 \mathrm{~d}$ ) double of normal growth 2030 e) half of population growth 2030, and f) population growth rate 2030

Population growth rate demand projection is overestimated and non-realistic; it indicated that all the agriculture land is projected to be converted into built up area and then encroach of forest is likely to start (Fig. 7). Half of the population growth rate scenario is under-estimated, and it cannot represent the actual LULC change features. Similarly, in the half of normal growth and double of the normal growth rate also underestimated and overestimated then the current LULC pattern respectively. In two extreme scenarios for 2045, all the agricultural area will be converted to impervious urban area. The statistical indicator Kappa value for 2014, 2016 and 2018 was respectively 0.75, 0.64 and 0.62. So, normal land use change is more practical or realistic compared to the others as it takes the historical LULC change pattern. 


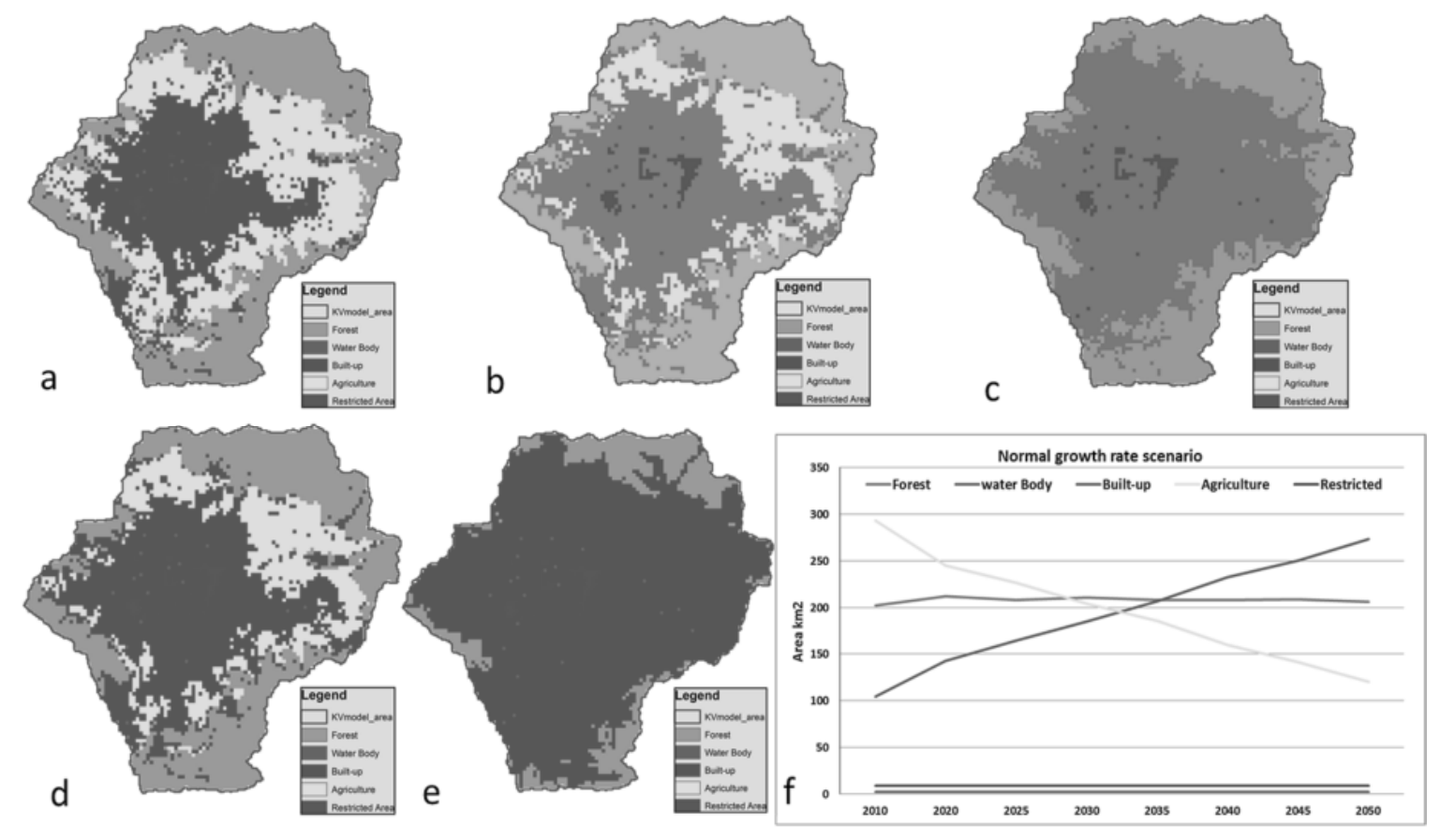

Fig 7: Projected LULC map of a) half of normal growth 2050 b) normal Growth 2050 c) Double of normal growth 2050 d) half of population growth 2050, e) population growth rate 2050, and f) LULC change by Normal growth pattern

The model assumed that urban development is concentrated in commercial areas and dense villages but the development is scattered due to high-cost of land and less open space in the existing market. The urbanization will be focused on the peri-urban road corridor so the future urban facilities and management will be concentrated in these locations.

\subsection{Analysis of projected CLUE-S LULC Maps}

The LULC change pattern of the basin was formulated through the conversion matrix of normal growth rate scenario as per Table 4. In an overall, agriculture and forest land is projected to reduce by $20.4 \%$ $(125.05 \mathrm{~km} 2)$ and $0.9 \%(5.51 \mathrm{~km} 2)$ respectively during 2020 to 2050 . The total built area is projected to increase by $21.3 \%(130.57 \mathrm{~km} 2)$ (Table 4$)$.

Table 4 LULC conversion matrix during 2020 to 2050

\begin{tabular}{|c|c|c|c|c|c|c|c|}
\hline & \multirow{2}{*}{ LULC } & \multicolumn{6}{|c|}{ Land Use/Cover $2050(\%)$} \\
\hline & & \multirow{2}{*}{$\begin{array}{c}\begin{array}{c}\text { Agriculture } \\
\text { Land }\end{array} \\
19.7\end{array}$} & \multirow{2}{*}{$\begin{array}{c}\text { Built- } \\
\text { Up } \\
19.6\end{array}$} & \multirow{2}{*}{$\begin{array}{c}\text { Forest } \\
0.8\end{array}$} & \multirow{2}{*}{$\begin{array}{c}\text { Restricted } \\
\text { Area } \\
-\end{array}$} & \multirow{2}{*}{$\begin{array}{l}\text { Water- } \\
\text { Body } \\
-\end{array}$} & \multirow{2}{*}{$\begin{array}{r}\begin{array}{r}\text { Grand } \\
\text { Total }\end{array} \\
40.1\end{array}$} \\
\hline$e^{0}$ & Agriculture Land & & & & & & \\
\hline \multirow{5}{*}{ 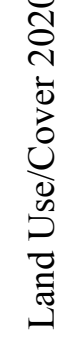 } & Built-Up & - & 23.4 & - & - & - & 23.4 \\
\hline & Forest & - & 1.7 & 33.00 & - & - & 34.7 \\
\hline & Restricted Area & - & - & - & 1.5 & - & 1.5 \\
\hline & Water Body & - & - & - & - & 0.3 & 0.3 \\
\hline & Grand Total & 19.7 & 44.7 & 33.8 & 1.5 & 0.3 & 100.0 \\
\hline
\end{tabular}


Within three decades, half of the agricultural land of the $\mathrm{KV}$ is projected to shift into the urban area. If the current level of urbanization continues as usual, more fertile land will be converted to built-up area. Also, the open space used as recreational areas of the KV might decline. In the future, the agricultural production will be decreased due to the loss of fertile land and increase food deficiency. So, fragmentation of land parcel and hazard urbanization creates more vulnerable the urban environments.

\section{Conclusion}

The urbanization pattern of the Kathmandu Valley was assessed through the historical LULC change by increasing the built-up area. Historical LULC map was generated through the USGS web portal and analyzed through the GIS environment. The remarkable Kappa coefficients between the two maps represent the credible analysis of the outputs. From the observation during the 2010-2018 the built-up areas was increased by $4.96 \%$ and the agricultural area was decreased by $6.51 \%$. The conversion of land use practice clearly indicates that the more resources will be required in the peri-urban area. For the future projection analysis, five different scenarios were taken based on LULC change and the population increment rate of the valley. Nine driving forces were used based on the relation between the driving forces and the LULC type. The coefficients and relation was verified through the logistic regression model and the receiver operating characteristics curve. The future LULC change scenarios considering five different scenarios and driving forces in a CLUE-S model underlined that the normal growth rate scenario provided the robust results when compare with the others. The depicted model highlights that the agricultural land would decline at the rate of $6.5 \%$ due to increment of $4.96 \%$ of built-up areas. The simulation of the CLUE-S model indicated that the urban built-up area was increased by $21.4 \%$ by reducing the agriculture and forest area by the $20.5 \%$ and $0.9 \%$ respectively. Nearby 4 $\mathrm{km}^{2}$ ofthe fertile and open land will be converted to the built-up due to the rapid urbanization per decade. Such increased urbanization process demands more resources and physical facilities for management of the urban environment.

\section{References}

1. Almeida, C.M., Gleriani, J.M., Castejon, E.F., Soares-Filho, B.S., 2008. "Using neural networks and cellular automata for modelling intra-urban land-use dynamics." Int. J. Geogr. Inf. Sci. 22, 943-963. https://doi.org/10.1080/13658810701731168

2. CBoS, 2011. "Nepal Census 2011".

3. CBS, N., 2012. "National population and housing census 2011", National Report.

4. Cohen, J., 1960. "A coefficient of agreement for nominal scales". Educ. Psychol. Meas. 20, 37-46.

5. Dahal, A., Khanal, R., Mishra, B.K., 2019. "Identification of critical location for enhancing groundwater recharge in Kathmandu Valley, Nepal." Groundw. Sustain. Dev. 9, 100253. https://doi.org/10.1016/j.gsd.2019.100253

6. DHM, 2015. "Hydrological records of Nepal, streamflow summary, updated version." Department of Hydrology and Meteorology: Goverment of Nepal, Ministry of Water Resources, Kathmandu.

7. Ishtiaque, A., Shrestha, M., Chhetri, N., 2017. "Rapid urban growth in the Kathmandu Valley, Nepal: Monitoring land use land cover dynamics of a himalayan city with landsat imageries." Environments 4, 72.

8. Jiang, W., Chen, Z., Lei, X., Jia, K., Wu, Y., 2015. "Simulating urban land use change by incorporating an autologistic regression model into a CLUE-S model." J. Geogr. Sci. 25, 836-850. https://doi.org/10.1007/s11442-015-1205-8

9. Kim, O., 2010. "Comparison of Two GIS based Land Change Modules for Constructing REDD Baselines in Bolivia.", in: Paper Presented at the AAG Annual Meeting, Washington, DC. Washington, DC.

10. Lamichhane, S., Shakya, N.M., 2020. Journal of Hydrology: "Regional Studies Shallow aquifer 
groundwater dynamics due to land use / cover change in highly urbanized basin: The case of Kathmandu Valley". J. Hydrol. Reg. Stud. 30, 100707. https://doi.org/10.1016/j.ejrh.2020.100707

11. Lamichhane, S., Shakya, N.M., 2019a. "Alteration of groundwater recharge areas due to land use/cover change in Kathmandu Valley, Nepal." J. Hydrol. Reg. Stud. 26, 100635. https://doi.org/10.1016/j.ejrh.2019.100635

12. Lamichhane, S., Shakya, N.M., 2019b. "Integrated Assessment of Climate Change and Land Use Change Impacts on Hydrology in the Kathmandu Valley Watershed, Central Nepal." Water (Switzerland) 11, 1-17. https://doi.org/10.3390/w11102059

13. Li, X., Yeh, A.G.O., 2002. "Neural-network-based cellular automata for simulating multiple land use changes using GIS." Int. J. Geogr. Inf. Sci. 16, 323-343. https://doi.org/10.1080/13658810210137004

14. Liu, M., Hu, Y., Zhang, W., Zhu, J., Chen, H., Xi, F., 2011. "Application of land-use change model in guiding regional planning: A case study in Hun-Taizi River watershed, Northeast China." Chinese Geogr. Sci. 21, 609.

15. MoUD, 2017. National Urban Development Strategy, "National Urban Development Strategy." https://doi.org/10.1017/CBO9781107415324.004

16. Paudel, B., Zhang, Y. li, Li, S. cheng, Liu, L. shan, Wu, X., Khanal, N.R., 2016. "Review of studies on land use and land cover change in Nepal." J. Mt. Sci. 13, 643-660. https://doi.org/10.1007/s11629-015-3604-9

17. Pointius, R.G., Schneider, L.C., 2001. "Land-cover change model validation by an ROC method for the Ipswich watershed, Massachusetts, USA." Agric. Ecosyst. Environ. 85, 239-248. https://doi.org/10.4018/978-1-61692-871-1.ch003

18. Praskievicz, S., Chang, H., 2011. "Impacts of climate change and urban development on water resources in the Tualatin River Basin", Oregon. Ann. Assoc. Am. Geogr. 101, 249-271.

19. Pratomoatmojo, N.A., 2018. "LanduseSim Algorithm: Land use change modelling by means of Cellular Automata and Geographic Information System." IOP Conf. Ser. Earth Environ. Sci. 202. https://doi.org/10.1088/1755-1315/202/1/012020

20. Rimal, B., Zhang, L., Fu, D., Kunwar, R., Zhai, Y., 2017. "Monitoring urban growth and the nepal earthquake 2015 for sustainability of Kathmandu Valley", Nepal. Land 6, 42.

21. Rimal, B., Zhang, L., Keshtkar, H., Haack, B.N., Rijal, S., Zhang, P., 2018. "Land use/land cover dynamics and modeling of urban land expansion by the integration of cellular automata and markov chain." ISPRS Int. J. Geo-Information 7. https://doi.org/10.3390/ijgi7040154

22. Rosner, B., 2010. Fundamentals of Biostatistics (Seventh Edition), "Fundamentals of Biostatistics." Harvard University. https://doi.org/10.5005/jp/books/10313

23. Shrestha, S., Bhatta, B., Shrestha, M., Shrestha, P.K., 2018. "Integrated assessment of the climate and landuse change impact on hydrology and water quality in the Songkhram River Basin", Thailand. Sci. Total Environ. 643, 1610-1622.

24. Soares-Filho, Rodrigues, H., Costa, W., 2009. "Modeling environmental dynamics with Dinamica EGO." Inst. Geociências - Cent. Sensoriamento Remoto 114. https://doi.org/10.13140/RG.2.1.5179.4641

25. Stephanie, M., Ceri, W.H., S.J., O., 2001. "Evaluating presence - absence models in ecology: the need to account for prevalence." J. Appl. Ecol. 38, 921-931. https://doi.org/10.1080/09613210110101185

26. Tang, J., Wang, L., Yao, Z., 2007. "Spatio-temporal urban landscape change analysis using the Markov chain model and a modified genetic algorithm." Int. J. Remote Sens. 28, 3255-3271. https://doi.org/10.1080/01431160600962749

27. Thapa, R.B., Murayama, Y., 2012. "Scenario based urban growth allocation in Kathmandu Valley", Nepal. Landsc. Urban Plan. 105, 140-148.

jacem, Vol 6, $2021 \quad$ Land Use Land Cover(LULC) Change Projection in Kathmandu Valley using the CLUE-S Model 
https://doi.org/10.1016/j.landurbplan.2011.12.007

28. Thapa, R.B., Murayama, Y., 2011. "Urban growth modeling of Kathmandu metropolitan region", Nepal. Comput. Environ. Urban Syst. 35, 25-34. https://doi.org/10.1016/j.compenvurbsys.2010.07.005

29. Thapa, S., Shrestha, A., Lamichhane, S., Adhikari, R., Gautam, D., 2020. "Catchment-scale flood hazard mapping and flood vulnerability analysis of residential buildings: The case of Khando River in eastern Nepal." J. Hydrol. Reg. Stud. 30, 100704. https://doi.org/10.1016/j.ejrh.2020.100704

30. Tran, D.X., Pla, F., Latorre-Carmona, P., Myint, S.W., Caetano, M., Kieu, H. V., 2017. "Characterizing the relationship between land use land cover change and land surface temperature." ISPRS J. Photogramm. Remote Sens. 124, 119-132. https://doi.org/10.1016/j.isprsjprs.2017.01.001

31. UN DESA, 2018. "World Urbanization Prospects", Demographic Research. https://doi.org/10.4054/demres.2005.12.9

32. Van Hear, N., Bakewell, O., Long, K., 2018. "Push-pull plus: reconsidering the drivers of migration". J. Ethn. Migr. Stud. 44, 927-944. https://doi.org/10.1080/1369183X.2017.1384135

33. Verburg, P., 2010. The CLUE model. "Hands-on Exercises. Course Material, in: The CLUE Model." Hands-on Exercises. Course Material. Institute for Environmental Studies, University of Amsterdam.

34. Verburg, P.H., Soepboer, W., Veldkamp, A., Limpiada, R., Espaldon, V., Mastura, S.S.A., 2002. "Modeling the spatial dynamics of regional land use: The CLUE-S model." Environ. Manage. 30, 391-405. https://doi.org/10.1007/s00267-002-2630-x

35. Yin, J., Yin, Z., Zhong, H., Xu, S., Hu, X., Wang, J., Wu, J., 2011. "Monitoring urban expansion and land use/land cover changes of Shanghai metropolitan area during the transitional economy (1979-2009) in China. Environ." Monit. Assess. 177, 609-621. https://doi.org/10.1007/s10661-0101660-8

36. Zhou, F., Xu, Y., Chen, Y., Xu, C.-Y., Gao, Y., Du, J., 2013. "Hydrological response to urbanization at different spatio-temporal scales simulated by coupling of CLUE-S and the SWAT model in the Yangtze River Delta region." J. Hydrol. 485, 113-125. 